\title{
Cultural Heritage and Mobile Technologies - Towards a Bibliography (1938-2015)
}

\author{
Cristian CIUREA \\ The Bucharest University of Economic Studies, Bucharest, Romania \\ cristian.ciurea@ie.ase.ro
}

The paper provides a survey of the scientific literature on cultural economy and applications of modern Information and Communication Technologies (ICT) in cultural sector with particular emphasis on the implementation of virtual exhibitions on mobile devices. The selected literature is presented for the period 1938-2015. A total of 100 articles, conference papers and books are enlisted according to the selected application area. The paper objective is to provide a bibliography as a resource for those that are interested in the field.

Keywords: Bibliography, Mobile Technologies, Virtual Exhibitions, Cultural Heritage

$\mathbf{1}^{1}$ Introduction

In the last years, the evolution of internet and information and communication technologies was very dynamic and had a significant impact on all human activity fields. The internet changed the way in which people are communicating and the manner in which they are working. Now, it is possible to work on a worldwide project from home or from an office located anywhere around the world.

The rapid development and growth of mobile technologies and applications and the hardware evolutions have made possible to access personal and professional resources anytime and from anywhere.

In [74] is presented that the evolution of new solutions in the field of information and communication technologies gives new opportunities to promote and valorize the cultural heritage elements. The potential offered by mobile technologies and the increased number of mobile devices that can process multimedia content, both offline and online, facilitates the feasibility of creating online virtual exhibitions.

These changes regarding the technology evolution and their impact on human life have implications in all fields of activities, including the cultural field.

The museums and libraries are forced to digitize their collections in order to make them available online, on their own websites, on different portals that aggregate them, like
Europeana (http://www.europeana.eu), or to publish them in virtual exhibitions.

The advantages of turning physical objects into digital ones are obvious: it prevents them from destruction and provides publication opportunities that not existed before.

Museums and libraries are confronted with a situation that they never face before. They must be competitive on the information market, in order to survive and attract many visitors that will bring them revenues.

In order to attract visitors, cultural institutions are creating exhibitions with special occasions. In order to make these exhibitions accessible by a great number of visitors, they must be transformed in virtual exhibitions and must be published online. The good news is there are available on the market advanced ICT platforms to create virtual exhibitions. A representative example is MOVIO already utilized in ATHENA Plus project [85] [86].

Generally, the concept of virtual exhibition is defined as an online dynamic web-based and hyper-textual collection, which is dedicated to a specific theme or topic, concept or idea. Many virtual exhibitions are attributed to museums or libraries, in order to make visible their collections to the visitors [52].

Coming back to the context of rapid growth of mobile technologies, in order to increase the visibility of virtual exhibitions, they must be implemented as native mobile applications, available for main mobile operating systems, such as Android, iOS, 
Windows Phone, or such as web applications that have responsive interface, which adapts on different screen sizes and resolutions.

The paper is intended to highlight several of the main works published in the field of usage of ITC in the cultural domain with particular emphasis on virtual exhibitions, cultural heritage and mobile technologies, in order to establish the current state of researches in the field of implementation of virtual exhibitions on mobile devices.

Some very good examples of a similar bibliography are presented at the following addresses:

- a bibliography in the field of DSS (Decision Support Systems): http://www.cif.ulbsibiu.ro/mariusc/bibliog raphySSD.htm

- a bibliography about PSO (Particle Swarm Optimization):

http://www.swarmintelligence.org/bibliog raphy.php

The references that are presented at the end of this paper represents a sample until an extended bibliography will be ready.

\section{Methodology}

To evaluate the evolution of the domain, a list of 100 relevant books and papers presented at prestigious conference or published in scientific journals were analyzed. Parts of the current bibliographical list were included in previous papers published by the author on the specified topic. For each source from the bibliographical list, the author searched for an online reference to the integral work (paper or book), in order to make it available for readers interested on the topic. For the sources that does not have a hyperlink, any online reference to the complete paper or book was not found or was not accessible for free. Some of the books were consulted from special online databases and from dedicated libraries.

\section{Conclusions}

The current list of bibliographical sources is intended to represent a starting reference for the people interested in the field of cultural heritage and information and communication technologies. The bibliography will be updated, and extended and it will be published as a web page with hyperlinks to each source.

\section{Acknowledgements}

This paper is supported by the Sectorial Operational Programme Human Resources Development (SOP HRD), financed from the European Social Fund and by the Romanian Government under the contract number SOP HRD/159/1.5/S/136077, and by the Athena Plus project (CIP Framework Programme 2007-2013, Grant agreement no. 325098, http://www.athenaplus.eu).

The author is grateful to Prof. F. G. FILIP for the idea of this research and useful suggestions.

\section{References (sorted by year)}

\section{8}

[1] H. G. Wells, World Brain, Methuen \& Co., London, 1938, Available at: https://ebooks.adelaide.edu.au/w/wells/h g/world brain/

\section{5}

[2] J. C. R. Licklider, Libraries of the future. Cambridge, Mass: MIT Press, 1965, Available at: https://comminfo.rutgers.edu/ tefko/Cou rses/e553/Readings/Licklider\%20Librari es $\% 20$ of $\% 20$ the $\% 20$ future $\% 201965 . p d f$

\section{8}

[3] R. E. Kahn, V. G. Cerf, The digital library project. Volume 1: the world of knowbots. An open architecture and a plan for its development [online] Corp. for National Research Initiative, 1968. Available at: http://www.cnri.reston.va.us/kahn-cerf$\underline{88 . p d f}$

\section{9}

[4] T. W. Adorno, M. Horkheimer, The dialectics of enlightenment. Trans. John Cumming. London: Verso, 1979. 


\section{1}

[5] T. W. Adorno, The culture industry: selected essays on mass culture. London: Rutledge, 1991.

[6] M. Dertouzos, Building the Information Marketplace, Technology Reviews 94(1), 1991, pp. 29-40.

\section{2}

[7] J. H. Saltzer, "Technology networks and the library of the year 2000," in A. Bensoussan, J. P. Verjus (Eds.). Future technologies on computer science, control and applied mathematics. Berlin: Springer Verlag, 1992, pp. 51-67, Available at: http://dx.doi.org/10.1007/3540-56320-2 52

\section{4}

[8] M. Bangemann, Europe and global information society. Report to European Council. June 24-25, 1994, [online], Available at: http://www.cyberrights.org/documents/bangemann.htm

[9] E. Brown, "The Future of Art at the Smithsonian," American Art, Vol. 8, No. 3-4, Summer/Fall 1994.

\section{6}

[10] F. G. Filip, "Information Technologies in Cultural Institutions," Studies in Informatics and Control, Vol. 6, 1996, pp. 385-400.

[11] A. De Michelis, "VENIVA ESPRIT project and the cultural heritage as a natural resource for Europe," in V. Cappelini, J. Hemsley (Eds.). Proceedings EVA'96, 1996, Florence, Italy.

[12] F. G. Filip, “Tehnologiile informatice și valorificarea patrimoniului cultural national," Academica, 1996, pp. 22-24.

\section{7}

[13] A. Brosegan, A. De Michelis, L. Romeo, The venetian virtual archive project: cultural heritage and online publishing, in Electronic Publishing 1997; New Models and Opportunities, Proc. of an ICCC/IFIP Conference, 14-16 April
1997, University of Kent, Canterbury, UK. ELPUB, pp. 317-325.

[14] M. Dertouzos, What it will be? How the new world of information will change our lives. New York: Harper Edge, 1997.

[15] D. Silver, "Interfacing American culture: the perils and potential of virtual exhibitions," American Quarterly 49(4), 1997, pp. 825-850, Available at: http://dx.doi.org/10.1353/aq.1997.0038

[16] James E. Melzer, Kirk Wayne Moffitt, Head-mounted displays: designing for the user, McGraw-Hill, 1997.

[17] K. Jones-Garmil, The Wired Museum: Emerging Technology \& Changing Paradigms. Introduction by Maxwell Anderson. American Association of Museums, 1997.

\section{8}

[18] NSF, Digital libraries initiatives: phase 2 [online], 1998, Available at: http://www.nsf.gov/pubs/1998/nsf9863/n sf9863.htm

[19] D. Hazen, J. Horrell, J. Merrill-Oldham, "Selecting Research Collections for Digitization," Council on Library and Information Resources, August 1998.

\section{9}

[20] C. Debainne-Francfort, The Search for Ancient China. Discoveries. New York: Harry N. Abrams, 1999, ISBN 978-08109-2850-3.

[21] A. Smith, "Why Digitize?" Council on Library and Information Resources, 1999.

[22] M. Shapiro, B. I. Miller, A Museum Guide to Copyright and Trademark, American Association of Museums, 1999.

\section{0}

[23] P. Walsh, "The new paintbrush: seeing technology and the museums as metaphor," Journal of the American Society of Information Science 51(1), 2000, pp. 39-48, Available at: http://dx.doi.org/10.1002/(SICI)1097- 
4571(2000)51:1<39::AIDASI7>3.0.CO;2-Y

[24] A. R. Kenney, O. Y. Rieger, Moving Theory into Practice: Digital Imaging for Libraries and Archives, Research Libraries Group, 2000.

\section{1}

[25] F. G. Filip, D. A. Donciulescu, C. I. Filip, "A Cybernetic Model of Computerization of the Cultural Heritage," Computer Science Journal of Moldova, Vol. 9, No. 2(26), 2001, pp. 101-112, Available at: http://tempo.math.md/files/csjm/v9n2/v9-n2-(pp101-112).pdf

[26] F. G. Filip, "Catre o economie a culturii si o infrastructura informationala intelectuala," Academica, Vol. XI, No. 12 (132), 2001, pp. 12-13.

[27] Salzburg Research, Europe's memory institutions on their way into the digital cultural economy. A DigiCULT Study. Salzburg Research, 2001.

[28] D. Throsby, Economics and culture. Cambridge: Cambridge University Press, 2001.

[29] G. Harper, Crash Course in Copyright, University of Texas, 2001.

[30] A. Smith, "Building and Sustaining Digital Collections: Models for Libraries and Museums," Council on Libraries and Information Resources, 2001, Available at: http://www.clir.org/pubs/reports/pub100/ pub100.pdf

\section{3}

[31] G. Lepouras, A. Katifori, C. Vassilakis, D. Charitos, "Real exhibitions in a Virtual Museum," Virtual Reality Journal, Springer-Verlag, Vol 7, No 2, 2003, pp. 120-128.

[32] M. Patel, M. White, K. Walczak, P. Sayd, "Digitization to Presentation Building Virtual Museum Exhibitions," Proceedings of International Conference on Vision, Video and Graphics, Bath, UK; Editor: Peter Hall and Phil Willis; July 2003, Available at: http://citeseerx.ist.psu.edu/viewdoc/dow nload?doi=10.1.1.121.6887\&rep=rep1\&t ype $=$ pdf

[33] K. Walczak, W. Cellary, "X-VRML for Advanced Virtual Reality Applications," Computer, vol. 36, no. 3, March 2003, pp. 89-92, Available at: http://www.researchgate.net/profile/Woj ciech Cellary/publication/2955867 XVRML for advanced virtual reality ap plications/links/02bfe50dc853cee85d000 000.pdf

[34] D. Zorich, "A Survey of Digital Cultural Heritage Initiatives and Their Sustainability Concerns," Council on Library and Information Resources, June 2003, Available at: http://www.clir.org/pubs/reports/pub118/ pub118.pdf

\section{4}

[35] C. Leadbeater, P. Miller, The Pro-Am Revolution: how enthusiasts are changing our economy and society [online] Demos, London, 2004. Available

at: http://www.demos.co.uk/files/proamrevo lutionfinal.pdf?1240939425

[36] A. Kaye, P. Poletto, "Virtual vs. Physical: Creating On-Line Educational Experiences through Design," Museums and the Web, 2004, Available at: http://www.museumsandtheweb.com/m w2004/papers/kaye/kaye.html

[37] S. K. F. Tobias, H. Höllerer, Mobile Augmented Reality, Telegeoinformatics: Location-Based Computing and Services, $\mathrm{H}$ Karimi and A. Hammad (eds.), Taylor \& Francis Books Ltd., 2004.

[38] M. White; N. Mourkoussis; J. Darcy; P. Petridis; F. Liarokapis; P. Lister; K. Walczak; K. Wojciechowski; W. Cellary; J. Chmielewski; M. Stawniak; W. Wiza; M. Patel; J. Stevenson; J. Manley; F. Giorgini; P. Sayd; F. Gaspard, ARCO - an architecture for digitization, management and presentation of virtual exhibitions, Computer Graphics International, 2004. 
Proceedings, pp. 622, 625, 19-19 June 2004.

[39] S. Dietz, H. Besser, A. Borda, K. Geber, "The Virtual Museum (of Canada): The Next Generation," Canadian Heritage Information Network, 2004.

[40] L. Bishoff, N. Allen, "Business Planning for Cultural Heritage Institutions," Council on Library and Information Resources, 2004, Available at: http://www.clir.org/pubs/reports/pub124/ pub124.pdf

[41] K. Hamma, "The Role of Museums in Online Teaching, Learning, and Research." In Sharing Digital Resources, WebWise 2004, vol. 9, no. 5, May 3, 2004.

\section{5}

[42] A. Alzua-Sorzabal, M. T. Linaza, M. Abad, L. Arretxea, A. Susperregui, "Interface Evaluation for Cultural Heritage Applications: the case of FERRUM exhibition," The 6th International Symposium on Virtual Reality, Archaeology and Cultural Heritage (VAST 2005), The Eurographics Association, 2005.

[43] K. Hamma, "Public Domain Art in an Age of Easier Mechanical Reproducibility." D-Lib Magazine, November 2005.

\section{6}

[44] A. Bruns, "Towards produsage: futures for user-led content production," in F. Sudweeks, H. Hrachovec, C. Ess (Eds.). Proceedings Cultural Attitudes towards Communication and Technology, 2006, Tartu, Estonia, pp. 275-284 [online], Available at: http://eprints.qut.edu.au/4863/1/4863 1. pdf

[45] H. Jenkins, Fans, bloggers and gamers. Exploiting participatory culture, New York: New York University Press, 2006.

[46] KEA, The economy of culture in Europe. A study for the European Commission [online]. KEA European Affairs, 2006. Available at: http://ec.europa.eu/culture/library/studies /cultural-economy en.pdf

[47] P. Lester, "Is the virtual exhibition the successor to the physical," Journal of the Society of Archivists 27(1), 2006, pp. 85-101, Available at: http://dx.doi.org/10.1080/000398106006 91304

[48] F. G. Filip, "Economia culturii si bibliotecile digitale," Top Business, No. 6, 2006, pp. 10.

\section{7}

[49] A. Bruns, "Produsage: towards a broader framework for user-led content creation," in Proceedings "Creativity \& Cognition 6", Washington, DC, 2007 [online], Available from Internet: http://eprints.qut.edu.au/6623/1/6623.pdf

[50] J. O'Connor, The cultural and creative industries: a literature review [online]. $2^{\text {nd }}$ ed. Creativity, Culture and Education, Newcastle upon Tyne Arts Council, 2007, Available at: http://www.creativitycultureeducation.or g/wp-content/uploads/CCE-lit-reviewcreative-cultural-industries-257.pdf

[51] WF, Staying ahead. Economic performance of the UK's creative industries. The Work Foundation, London, 2007.

\section{8}

[52] S. Foo, "Online Virtual Exhibitions: Concepts and Design Considerations," Journal of Library and Information Technology, Vol. 28, No. 4, July 2008, pp. 22-34, Available at: http://dx.doi.org/10.14429/djlit.28.4.194

[53] S. Galloway, The evidence base for arts and culture policy; a brief review of Scotland recent literature [online], 2008, Scotland Art Council. Available at: http://www.scottisharts.org.uk/resources/ publications/research/pdf/SAC $\% 20 \mathrm{Lit} \%$ 20Review\%20Executive\%20Summary.p df

[54] F. G. Filip, "Tehnologiile moderne si valorificarea patrimoniului cultural," Curentul, 14 March 2008, pp. 13. 
[55] P. Feliciati, M. T. Natale (eds.), Handbook of cultural web user interaction, First edition (September 2008), MINERVA EC Project, 2008.

\section{9}

[56] S. Foo, T. Y. Leng, D. G. Hoe-Lian, N. J. Cheong, "From Digital Archives to Virtual Exhibitions," In Theng, Y.L., Foo, S., Goh, H.L.D., \& Na, J.C. (Eds.) Handbook of Research on Digital Libraries: Design, Development and Impact, London: Information Science Reference (on imprint of ICL global), IGI Global, Hershey, 2009, pp. 88-101.

[57] C. K. Grinnell, "From consumer to prosumer to produser: who keeps shifting my paradigm? (We do!)," Public Culture 21(3): 2009, pp. 577-598. Available at: http://dx.doi.org/10.1215/089923632009-009

[58] H. Jenkins, What happened before You Tube, in I. Bugess, J. Green (Eds.). You Tube: on line video and participatory culture. Cambridge: Polity Press, 2009, pp. 109-125.

[59] A. M. Ronche, e-culture: cultural content in the digital age. Dordrecht: Springer Science and Business Media, 2009.

[60] H. L. Yen, "The role and integration of the digital libraries in e-learning," in Y.L. Theng, S. Foo, D. Goh, J.-C. Na (Eds.), Handbook of research on digital libraries: design, development and impact. London: Information Science Reference (on imprint of ICL global), 2009, pp. 476-480.

\section{0}

[61] G. Dumitrescu, F. G. Filip, A. Ioniţă, C. Lepădatu, "Open Source Eminescu's Manuscripts: A Digitization Experiment," Studies in Informatics and Control, Vol. 19, No. 1, 2010, pp. 79-84.

[62] European Commission, Green paper: unlocking the potential of cultural and creative industries [online]. Brussels, 2010, COM 2010/183. Available from
Internet: http://eur-lex.europa.eu/legalcontent/EN/TXT/?uri=CELEX:52010D $\mathrm{C} 0183$

[63] F. G. Filip, I. Cojocaru, "Economy of culture in the information society based on knowledge," in I. Nichifor, E. Severin (Eds.). Science and education policies in Central and Eastern Europe, Balkans, Caucasus and Baltic Countries. UNESCO BRESCE, Venice, 2010, pp. 110-120 [online], Available at: http://unesdoc.unesco.org/images/0018/0 01878/187823e.pdf

[64] A. Respício, F. Adam, G. Phillips-Wren, C. Teixeira, J. Telhada, Bridging the Socio-technical Gap in Decision Support Systems: Challenges for the Next Decade, IOS Press, 2010, pp. 600.

\section{1}

[65] J. Gomes, M. B. Carmo, A. P. Cláudio, "Creating and Assembling Virtual Exhibitions from Existing X3D Models," Docs.DI, 2011, Available at: http://hdl.handle.net/10455/6748

[66] L. Barile, Mobile technology for libraries: a list of mobile applications and resources for development, College \& Research Libraries News 72(4), 2011: pp. 222-228 [online], Available at: http://crln.acrl.org/content/72/4/222.full

[67] L. Tallon, "About that 1952 Sedeliijk Museum audioguide, and a certain Willem Sandburg," Musematic, 19 May 2011.

\section{2}

[68] J. A. Clark, Building mobile library applications. ALA TechSource, American Library Association, Chicago, $2012,130 \mathrm{pg}$.

[69] M. Dulong de Rosnay, J. C. De Matin, The digital public domain. Foundations of an open culture. Cambridge: Open Book Publishers, 2012, http://dx.doi.org/10.11647/OBP.0019

[70] J. Holden, J. Baltà, The public value of culture: a literature review (EENC, 2012) [online], 2012, Available at: 
http://www.eenc.info/news/the-publicvalue-of-culture-literature-review

[71] R. M. Kalfatovic, Creating a winning online exhibition. A guide for libraries, archives and museums. American Librares Association, Chicago, London, 2012, 137 pg.

[72] N. Proctor, (Ed.), Mobile apps for museums; the AAM guide to planning and strategy [online]. 2nd ed. American Alliance of Museums, 2012, Available at:

http://mobileappsformuseums.wordpress .com

[73] D. Rypkema, C. Cheng, Public private partnerships and heritage. $A$ practitioner's guide. Heritage Strategies International, Washington, 2012.

[74] M. T. Natale, S. Fernandez, M. Lopez (editors), Handbook on Virtual Exhibitions and Virtual Performances, version 1.0, Ministerio per i beni le activitta culturale and ICCU, Roma, Italy, August 2012, Available at: http://www.indicateproject.eu/getFile.php?id $=412$

[75] V. Dziekan, Virtuality and the Art of Exhibition. Curatorial Design for the Multimedia Museum, Chicago, IL: The University of Chicago Press, 2012.

\section{3}

[76] APWPT, Study on social and economic benefit of European, Austrian and German art, culture and creative industry [online], Association of Professional Wireless Production Technologies, 2013, Available at: http://www.apwpt.org/downloads/studys ocialecconomicbenefitmarch2013.pdf

[77] C. Dümcke, M. Gnedovsky, The social and economic value of cultural heritage: literature review [online], European Expert Network on Culture, 2013. Available at: http://www.eenc.info/wpcontent/uploads/2013/08/CD $\% \mathrm{C} 3 \% \mathrm{BCm}$ cke-MGnedovsky-Cultural-HeritageLiterature-Review-July-2013.pdf

[78] F. G. Filip, ITC and culture economy. Lecture held at School of Management, the University of the Chinese Academy of Sciences on 14 May 2013 [online], Available at: http://www.biblacad.ro/publicatii_propri i/FFilip\%282013\%29Beijing.pdf

[79] D. Hesmondhalagh, The culture industry. $3^{\text {rd }}$ ed. Sage Publications Ltd., 2013.

[80] J. Heggestuen, One in Every 5 People in the World Own a Smartphone, One in Every 17 Own a Tablet, 2013, Available at:

http://www.businessinsider.com/smartph one-and-tablet-penetration-2013-10

[81] T. Chatzidimitris; E. Kavakli; M. Economou; D. Gavalas, Mobile Augmented Reality edutainment applications for cultural institutions, 2013 Fourth International Conference on Information, Intelligence, Systems and Applications (IISA), pp.1,4, 10-12 July 2013.

[82] D. Petrelli, L. Ciolfi, D. van Dijk, E. Hornecker, E. Not, A. Schmidt, "Integrating Material and Digital: A New Way for Cultural Heritage," ACM Interactions Magazine, Vol. 20, No. 4, 2013, pp. 58-63.

[83] J. Verboom, A. Payal, "Museum 2.0: A study into the culture of expertise within the museum blogosphere," First Monday - Peer-reviewed Journal on the Internet, Vol. 18, No. 8, 2013, Available at: http://firstmonday.org/ojs/index.php/fm/ article/view/4538/3735

[84] P. Pocatilu, C. Boja, C. Ciurea, "Syncing Mobile Applications with Cloud Storage Services," Informatica Economică, Vol. 17, No. 2, 2013, pp. 96-108, Available at: http://revistaie.ase.ro/content $/ 66 / 08 \% 20$ \%20Pocatilu, \%20Boja,\%20Ciurea.pdf

[85] J. M. Darling, D. J. Vanoni, T. E. Levy, F. Kuester, "Enhancing the digital heritage experience from field to museum: User-centered system design of an augmented reality tablet application for cultural heritage," Digital Heritage International

Congress 
(DigitalHeritage), 2013, vol. 1, pp. 453, Oct. 28 2013-Nov. 12013.

\section{4}

[86] S. H. Minelli, M. T. Natale, B. Dierickx, P. Ongaro, D. Ugoletti, R. Saccoccio, M. Aguilar Santiago, "MOVIO: A semantic content management and valorisation approach for archives and cultural institutions," Girona 2014: Arxius i Indústries Culturals, 2014, Available at: http://www.girona.cat/web/ica2014/pone nts/textos/id234.pdf

[87] M. T. Natale, S. H. Minelli, B. Dierickx, P. Ongaro, M. Piccininno, D. Ugoletti, R. Saccoccio, A. Raggioli, "Exhibiting Intangible Cultural Heritage using MOVIO: a multilingual toolkit for creating curated digital exhibitions, made available by the AthenaPlus project," ICOM 2014 - Access and Understanding - Networking in the Digital Era: intangible Cultural Heritage, 2014, Available at: http://www.cidoc2014.de/images/sample data/cidoc/papers/H-

2 Natale Minelli_et-al paper.pdf

[88] CEU, Conclusions on cultural heritage as a strategic resource for sustainable Europe. Education, Youth, Culture and Sport Council Meeting, Brussels, 20 May 2014, [online] Council of the European Union. Available from Internet:

http://www.consilium.europa.eu/uedocs/ cms_data/docs/pressdata/en/educ/14270 $\underline{5 . p d f}$

[89] DEWG. 2014. Digital exhibitions working group [online], Available from Internet:

http://museumsdokumentation.de/joomla

[90] F. N., Heritage and economy [online]. Centre for International Heritage Activities, 2014. Available from Internet: $\quad$ http://www.heritageactivities.nl/drupal/book/export/html/918

[91] Gartner, Gartner says annual smartphones sales surpassed sales phones for the first time in 2013 [online],
2014 ,

Available

at:

www.gartner.com/newsroom/id/2665715

[92] PortioResearch, Mobile application futures 2013-2017 [online], 2014. Available

at:

http://www.portioresearch.com/en/major -reports/current-portfolio/mobileapplications-futures-2013-2017.aspx

[93] G. Dumitrescu, C. Lepadatu, C. Ciurea, "Creating Virtual Exhibitions for Educational and Cultural Development," Informatica Economică, Vol. 18, No. 1, 2014, pp. 102-110, Available at: http://www.revistaie.ase.ro/content/69/0 9\%20-

\%20Dumitrescu,\%20Lepadatu,\%20Ciur ea.pdf

[94] C. Ciurea, A. Zamfiroiu, A. Grosu, "Implementing Mobile Virtual Exhibition to Increase Cultural Heritage Visibility," Informatica Economică, Vol. 18, No. 2/2014, pp. 24-31, Available at: http://revistaie.ase.ro/content/70/03\%20\%20Ciurea,\%20Zamfiroiu, \%20Grosu.pd f

[95] C. Ciurea, C. Coseriu, C. Tudorache, "Implementing Mobile Applications for Virtual Exhibitions using Augmented Reality," Journal of Mobile, Embedded and Distributed Systems, Vol. 6, No. 3, 2014, ISSN 2067-4074, Available at: http://www.jmeds.eu/index.php/jmeds/ar ticle/download/Implementing Mobile A pplications for_Virtual_Exhibitions/pdf -

[96] C. Ciurea, C. Tudorache, "New Perspectives on the Development of Virtual Exhibitions for Mobile Devices," Economy Informatics, Vol. 14, No. 1, 2014, Available at: http://www.economyinformatics.ase.ro/c ontent/EN14/04\%20\%20Ciurea, \%20Tudorache.pdf

[97] C. Ciurea, G. Dumitrescu, C. Lepadatu, "The impact analysis of implementing virtual exhibitions for mobile devices on the access to national cultural heritage," Proceedings of 2nd International Conference 'Economic Scientific Research - Theoretical, Empirical and 
Practical Approaches', ESPERA 2014, 13-14 November 2014, Bucharest, Romania.

\section{5}

[98] F. G. Filip, "Colecţiile de patrimoniu în era digitală, în loc de o cronică a unui workshop," Workshop Colecţiile de patrimoniu în era digitală, Comunicări şi articole, 24-25 noiembrie 2014, Biblioteca Academiei Române, pp. 167177, Available at: http://www.biblacad.ro/workshop/Volu mWorkshopBAR_vf.pdf
[99] C. Ciurea, "Expoziţii virtuale şi modele de interacţiune între actanţii implicaţi," Workshop Colecţiile de patrimoniu în era digitală, Comunicări şi articole, 2425 noiembrie 2014, Biblioteca Academiei Române, pp. 71-83, Available at: http://www.biblacad.ro/workshop/Volu mWorkshopBAR vf.pdf

[100] P. Pocatilu, I. Ivan, A. Vișoiu, F. Alecu, A. Zamfiroiu, B. Iancu, Programarea aplicatiilor Android, ASE Publishing House, Bucharest, 2015, pg. 714.

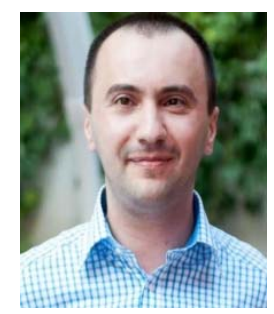

Cristian CIUREA is Assistant Professor at the Department of Economic Informatics and Cybernetics from Bucharest University of Economic Studies. He has graduated the Faculty of Economic Cybernetics, Statistics and Informatics from the Bucharest University of Economic Studies in $2007 . \mathrm{He}$ has a master in Informatics Project Management (2010) and a $\mathrm{PhD}$ in Economic Informatics (2011) from the Bucharest University of Economic Studies. Cristian has a solid background in computer science and is interested in collaborative systems related issues. Other fields of interest include software metrics, data structures, object oriented programming, windows applications programming, mobile devices programming and testing process automation for software quality assurance. 